\title{
THE ROCK WREN IN SASKATCHEWAN: STATUS AND DISTRIBUTION
}

WAYNE E. RENAUD, LGL Ltd.-environmental research associates, 44 Eglinton Ave. W., Toronto, Ontario, M4R 1A1.

Those who have spent time in the dry river valleys and badlands of the southwest will likely have made contact with the Rock Wren, a bird of drab plumage and mouse-like habits made conspicuous by its fine, farcarrying song. Although it is locally one of the more common summer residents of rock outcroppings and river breaks in southwestern Saskatchewan, surprisingly little has been written concerning its distribution and status in the province. Laurence Potter, one of the province's earliest resident naturalists who lived near Eastend from 1901 to 1943 , only once mentioned Rock Wrens in 29 short papers which he wrote on the status of birds in southwestern Saskatchewan. ${ }^{17}$ W. E. Godfrey's later work in the Cypress Hills centered on the forested uplands and on the north slope where there is little suitable Rock Wren habitat and, therefore, added little additional information. ${ }^{9} \mathrm{~A}$ nesting locality along the South Saskatchewan River has been briefly documented by J. F. Roy ${ }^{19}$, and a possible breeding record for Regina is given by Margaret Belcher. ${ }^{1}$ Information on the status of the Rock Wren in southeastern Saskatchewan will be provided in the forthcoming "Birds of the Qu'Appelle Valley" by E. M. Callin.

Most of the records included here are unpublished. Table 1 and Figure 1 summarize all records, together with the observers and sources, known to me through 1978. For the sake of brevity, further referencing o observers and sources, especially fo unpublished records, has been kep to a minimum.

\section{Historicai Records}

Evidently, the earliest record of the Rock Wren within the present boun daries of Saskatchewan was one observed at the "east end of the Cypress Hills" on 26 June 1894 by John Macoun who was employed by the Geological Survey of Canada." The following year the first specimen was collected by William Spreadborough along "Rocky" [Rock] Creek, southwest of Killdeer. ${ }^{14}$

The next reference was in 1917 when $H$. H. Mitchell collected specimens in the "Cypress Hills" for the National Museum of Canada (D. M. Richardson, pers. comm.); in 1921, $P$. A. Taverner and $H$. Laing collected additional specimens at Eastend. ${ }^{9}$ Mitchell recorded the first definite evidence of breeding, a nest with 8 eggs, in the "Cypress Hills" on 1 June $1925 .^{3}$

The earliest summary of the Rock Wren's status and distribution in Saskatchewan was in 1924: "Not common; noted, and found breeding, only in extreme southwest from Cypress Hills to Wood Mountain districts, in outcropping sandstone." 16

\section{Spring Arrival}

The earliest spring arrival date for 
Saskatchewan is 21 April (1978) near Eastend. There are only two other April records: 26 April (1932) and 28 April (1962), both at Regina. The earliest spring arrival dates at known breeding areas with several years of systematic observations were 1 May at Eastend (M. Gollop) [L. Potter's earliest record was 3 May], 5 May at Val Marie (J. D. Chandler), and 6 May at Matador I.B.P. Grassland.$^{15}$ In most lears, Rock Wrens are probably rare before the first week of May. No spring concentrations have been ecorded.

\section{Nesting}

Rock Wrens are evidently wellestablished on territories by the 3rd week of May. There are only three ecords of nests with eggs: 1 June 1925 in the Cypress Hills ( 8 fresh eggs), ${ }^{3} 20$ June 1959 in the Big Muddy Valley (2 eggs), and 20 June 1971 at the mouth of Swift Current Creek (5 eggs). An observation of a pair nestbuilding at Boundary Plateau on 25 June (1978) indicates that eggs may pe expected as late as July. Nestlings have been observed as early as 20 June at Skull Creek, and as late as 13 July at Matador I.B.P. Grassland. ${ }^{15}$ Fledged young in family groups have been observed from 8 July at Old Man On His Back Plateau to 18 August at Ravenscrag..$^{9}$

Most breeding records consist of bservations of adults carrying food nto crevices or holes. A nest in the Big Muddy Valley was located under a "small, flat rock" on top of a rocky hill (R. Carson, PNRS); another located along the South Saskatchewan River was "in a crevice in a vertical cliff ... 30 feet [9m] from the top of the cliff" (W. Harris, PNRS). At Muddy Lake, hear Unity, adults were feeding hestlings at a small hole (evidently created by running water) $2.5 \mathrm{~m}$ from he bottom of a steep slope of eroded sandstone (pers. obs.).
The meagre information on nesting chronology suggested that most nests are built in late May and eggs are present from at least the last week of May to the 3rd week of June (and probably into July); nestlings appear from the 3rd week of June to the 2nd week of July. Thereafter, until at least the 3rd week of August, family groups may occur throughout the breeding range.

\section{Fall Migration}

The latest fall record for Saskatchewan is 27 September (1927) in the Big Muddy Valley. Potter's latest observation in prime breeding habitat at Eastend was 15 September (1921). Fourteen Saskatchewan records for September suggest that Rock Wrens regularly remain long past the breeding season, even in areas north and east of the regular breeding range (e.g., Arm River Valley, Broadview, Buffalo Pound Lake, Floral, Pasqua Lake, Regina). No fall concentrations have been recorded.

\section{Distribution and Abundance}

The breeding range of the Rock Wren consists of several pockets and corridors in the grasslands and parklands of the south and southwest. Figure 2 summarizes the breeding distribution based on records in Table 1 and Figure 1.

No plot studies of breeding bird densities have been done in Rock Wren habitat; hence, there is no quantitative information on absolute numbers. However, the available information indicates that densities vary considerably within the species known range in the province.

One of the largest breeding populations inhabits the upper Frenchman River and associated coulees on the south slope of the Cypress Hills: "At Jones Peak alone 


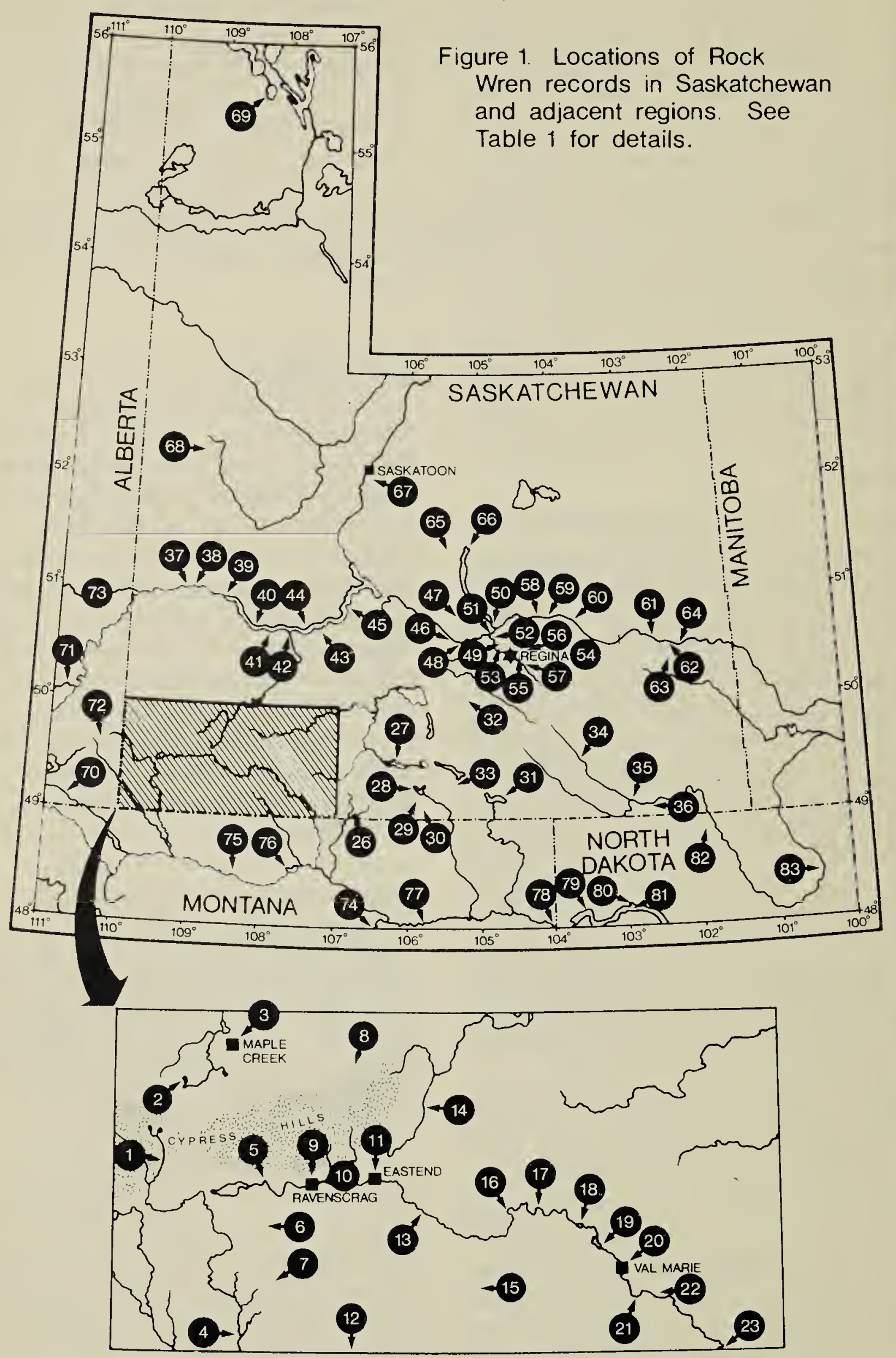




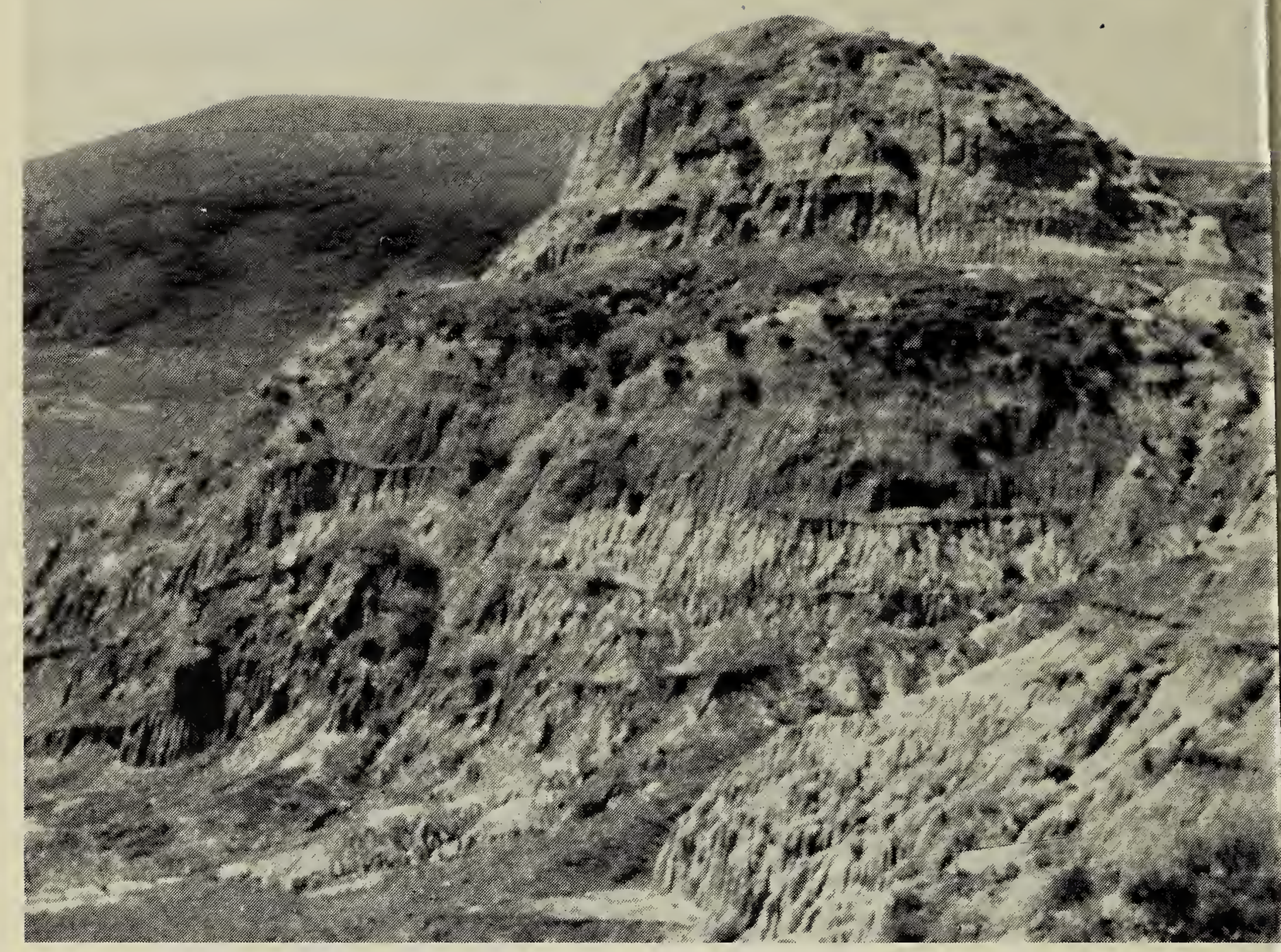

Muddy Lake hills near Unity, northern-most badlands in Saskatchewan and mos northerly breeding locality of the Rock Wren.

Wayne Renaud

along the eroded valley walls near Fife, Twelve-mile, Willow Bunch and Big Muddy lakes, and along Goose Creek near Rockglen. It breeds in at least small numbers locally north to the Avonlea badlands.

Along the Souris River drainage in Saskatchewan, and into North Dakota, the species is even more locally distributed. ${ }^{25}$ The largest numbers apparently occur in the Estevan spoil piles.

In the Qu'Appelle River drainage, the Rock Wren is a rare and irregular transient and summer resident; it was recorded in only 17 of 46 years from 1932 (first record) to 1978. About one third of the records were for 1959 , suggesting that a northward eruption had occurred. ${ }^{7}$ Assumed breeding at Pilot Butte near Regina and in the Qu'Appelle River Valley is based on circumstantial evidence since nc nests have been found. ${ }^{17}$ There are no records for the extreme east end of the Qu'Appelle Valley in Saskatchewan or for southwestern Manitoba.

The only other breeding locality is in a restricted area of badlands west of Muddy Lake (near Unity), about $110 \mathrm{~km}$ north of the nearest breeding areas on the South Saskatchewan River. Probably fewer than 10 pairs nest annually in this area (pers. obs.). Except at Muddy Lake near Unity and the north end of Last Mountain Lake, the species can probably be regarded as accidental north of $51^{\circ} \mathrm{N}$. The most northerly record was a Kazan Lake $\left(55^{\circ} 35^{\prime} \mathrm{N}\right.$.Lat.) well within the boundaries of the mixed wood forest. The occurrence of the Rock Wren at much more northerly latitudes at Churchill, 


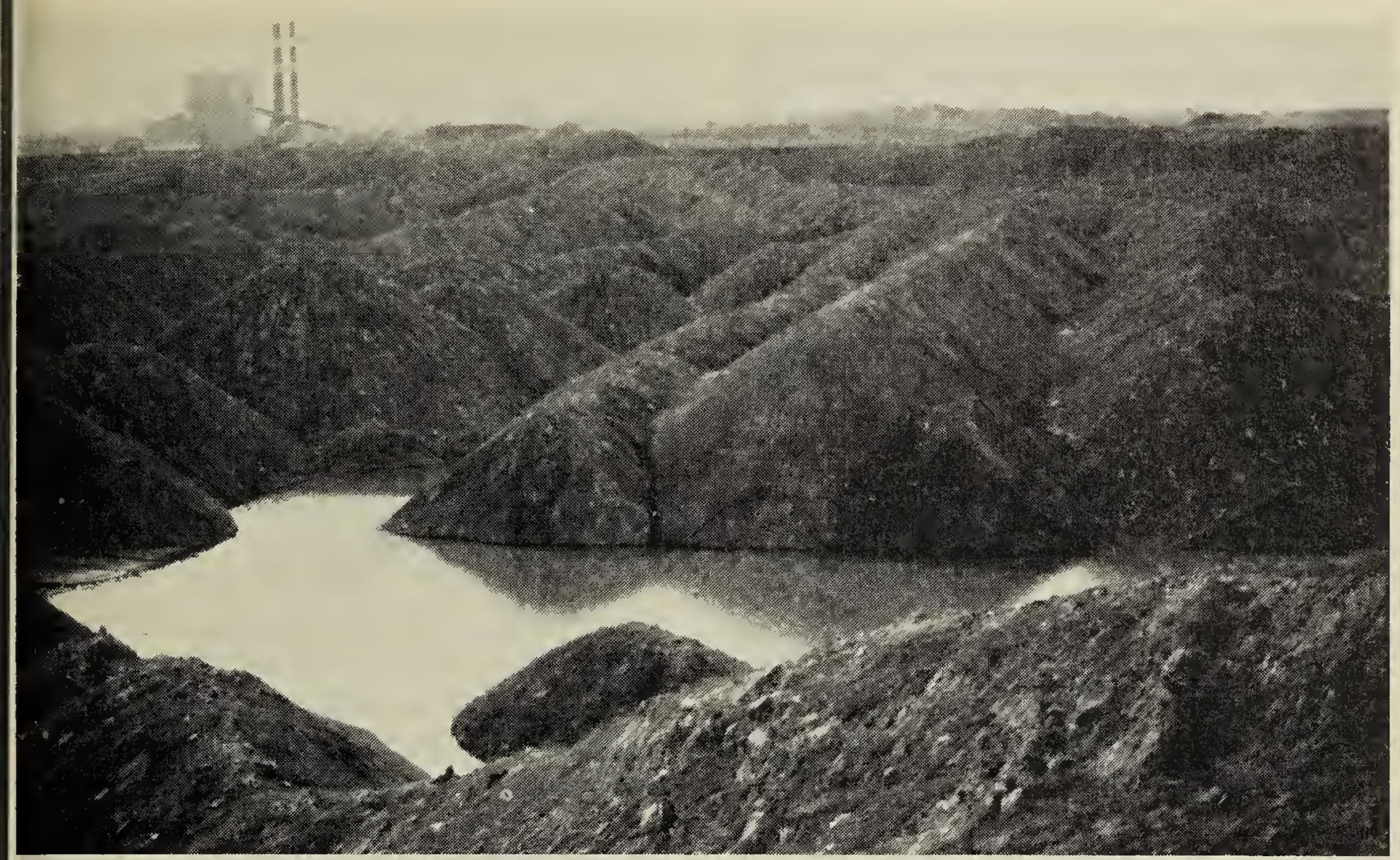

Spoil piles left after the strip-mining of coal in the Estevan area. The barren slopes with scattered fragments of shale provide habitat for the most easterly populations of nesting Rock Wrens in Canada.

Bob C. Godwin

Manitoba (as an accidental breeder) ${ }^{11}$, and at Fort Chipewyan, Alberta, on Lake Athabasca ${ }^{2}$, suggests that the species is an erratic wanderer and can be expected to occur, and possibly even breed, anywhere within Saskatchewan.

\section{Habitat}

Throughout the greater part of its range in Saskatchewan, the Rock Wren is confined to eroded rock outcroppings (i.e., badlands) and the sparsely-vegetated walls of river valleys. The important requisites appear to be a barren substrate over which the birds can forage, and crevices where nests can be built. The large numbers along the Frenchman River occur in exposures of sedimentary bedrock. Eroded outcroppings in the Killdeer badlands, at Boundary Plateau, at the west end of Old Man On His Back Plateau, near Avonlea, in the Wood Mountain-Big Muddy Valley area, and near Muddy Lake support regular breeding populations. Most, if not all, bedrock outcroppings on the prairies and parklands appear to support at least small numbers of nesting Rock Wrens. Along lower Swift Current Creek and the South Saskatchewan River from the Alberta border to Riverhurst, the species is much less common; the small numbers may be attributable both to the peripheral position of these areas relative to the main breeding range, as well as to habitat that is less suitable for Rock Wrens.

In the past century, the species has expanded its breeding range to include several man-made habitats. The most significant of these is along the Souris River near Estevan, where large numbers now nest in the spoil piles left following coal mining activities. R. C. Godwin (pers. comm.) described these man-made habitats: "Rock Wrens are found in only certain areas of the coal spoils at Estevan, their presence or absence being determined by the geology of the area and, most importantly, by the mining technique used to expose the coal. In the late 1880's coal was dug directly 
from coal seams exposed along the eroded sides of the Souris River. Strip mining with tractor-drawn scrapers in the 1930's created a slightly rolling topography. As the supporting technology improved, steam and electric shovels and low capacity draglines were used, thus creating ridges 4 to $7 \mathrm{~m}$ high. More recently, high capacity draglines have created ridges up to $12 \mathrm{~m}$ in height."

"With the new equipment allowing the mining of progressively deeper coal seams in the Ravenscrag formation, the spoil piles contain a greater amount of poorly consolidated quartz sands, clays, silts and friable shales. Due to moderate salinity, high sodium, low amounts of nitrogen and phosphorus, and the water-impermeable crusting of the soil created by high sodium content, these new soils are slow to be colonized by plants. This combination of factors results in steep, hard banks with little vegetation, and numerous rock crevices; ideal foraging and nesting habitat for Rock Wrens."
Elsewhere in Saskatchewan, Roc Wrens have been recorded numerous man-altered environments Within, and north of, the regula breeding range, Rock Wrens are often reported singing, anc presumably nesting, in gravel pits (e.g., Eastend, Imperial, Pilot Butte and in road cuts (e.g., Valeport). Or reservoirs, dams and causeways, the rock or concrete fill (rip-rap) placec on steep slopes to prevent wate erosion is sometimes used as forag ing and nesting habitat. Rock Wrens have been recorded in rip-rap at the Riverhurst Ferry (probably nesting), a Harris Reservoir and at Wascanz Lake. In Montana, some slopes of riprap (e.g., Fort Peck Dam) suppor considerable nesting populations ( $C$ M. Carlson, pers. comm.). Rock Wrens have also been seen foraging in woodpiles, on stone fences, on piles of cement blocks, and in culverts. Near Eastend, a family group of wrens that nested in a gravel pit was seen foraging on railway flatcars left near the nestsite. ${ }^{17}$

TABLE 1. Rock Wren records in Saskatchewan and adjacent regions. Locations are mapped in Fig. 1. A list of observers, correspondents, institutions and abbreviations follows this table. Initials of observer(s) are differentiated from record sources by a dash, e.g., 'FGB-KR pc' indicates that the observation was made by Fred G. Bard; the source of the record was Keith Roney, personal communication.

\section{SASKATCHEWAN}

\section{FRENCHMAN R.-CYPRESS HILLS}

1. ADAMS CK. $9 \mathrm{KM} \mathrm{N}$ OF MERRYFLAT. $\operatorname{Pr}$ ( 9 with food), Jn 23/78 (WR po).

2. HARRIS RES. 1 , Jy $9 / 77$ (WH SL pc).

3. MAPLE CK. 1 o col (SMNH), My 22/65 (WP-W-KR PC).

4. S OF SUPREME. "Several", Jn 19/41 (JDS-Soper 1970).

5. FRENCHMAN R. AT BELANGER CK. Family group, summer/74 (BG pc).

6. ROBSART. "Common", Jy-Ag/24 (MW-Williams 1946).

7. OLD MAN ON HIS BACK PLATEAU. 11, mostly juv; 3 o , 2 \% col, Jy 8/48 (WEGGodfrey 1950). 1 singing of , Jn 24/78 (WR po).

8. SKULL CK. 4 records: Jn 1/34 (1 bird); Jn 8/48 (1); Jn 20/55 (2ad:4yng); My 31/66 (2) (SM-MG pc).

9. RAVENSCRAG. $10 ; 1 q \mathrm{col}(\mathrm{SMNH}), \mathrm{Jn}$
$3 / 25$ (HHM-KR pc). $1 \sigma^{x} \mathrm{col}(\mathrm{SMNH}), \mathrm{Jn}$ $6 / 25$ (HHM-KR pc). "Family group", Ag 18/60 (RVF-Folker 1961). $8+$, Jy $8 / 77$ (WH SL PC).

10. EASTEND-RAVENSCRAG. Breeds; ESA: My 3; LFD: 15 Sp (LP-Bent 1948); nesting in gravel pit, 1930's (?) (LP-Potter 1932). Very common summer resident; ESA: My 1/76; LFD: Sp 13/75; 2 family groups in 1st 2 wks $\mathrm{Ag} / 75$ (MG pc).

11. EASTEND. 10 , Jn 26/1894 (JMMacoun \& Macoun 1909). "Not uncommon", 1921 (PT HL-Godfrey 1950). 30 o col (NMC), Jn 17/21 (HL-DR pc). $1 \mathrm{col}$ (NMC), Jn 22/21 (PT-DR pc). 1 o col. (SMNH), Jn 12/34 (FGB-KR pc). "Several", Jy 4/37 (JDS-Soper 1970). 20,1 \% col (ROM), My 25/39 (CH-DR pc). 1 t $\mathrm{col}(\mathrm{SMNH}), \mathrm{Jy} 8 / 51$ (LD-KR pC). 1, Anxiety Butte, Ap 21/74 (JWi pc).

12. BOUNDARY PLATEAU S OF 
STAYNOR HALL. 2 singing o , 1 q nest building, Jn 24/78 (WR po).

13. FRENCHMAN R. AT HWY. \#37. Several records: My 21/73 (4-5 wrens), My 2324/73, My 4/74, Sp 1/74, Jn 12/77 (3+), Jn 13/77, Sp 5/77 (1) (JWi pc).

14. SWIFT CURRENT CK. $11 \mathrm{KM} \mathrm{N} \& 3 \mathrm{~W}$ OF DOLLARD. "Several" singing $\delta$, JnJy/78 (GA pc).

15. CLIMAX. "Noted sparingly", Jn 16/42 (JDS-Soper 1970).

16. FRENCHMAN R. AT MULE CK. Singing ơ J. Jn-Jy/78 (GA pc).

17. FRENCHMAN R. $\left(49^{\circ} 25^{\prime} \mathrm{N} ; 108^{\circ} 04^{\prime} \mathrm{W}\right)$. 2 singing $o$, My 25-26/74 (WR CET SS AW po).

18. HUFF L. Probably breeds (MG pc).

19. FRENCHMAN R. AT NEWTON RES. 3 singing oे, My 27/74 (CET SS AW WR po). 20. VAL MARIE. 1, Jy 15/61 (RH-Hopper 1961).

21. FRENCHMAN R. AT PRAIRIE DOG BUTTE. "First seen" My 24/69 (JDS pc). "Nest in canyon", Jn 7/69 (JDC pc). 1 singing to, Jn 13/69 (JAW SW pc). "First seen", My 5/71 (JDC pC). 1, My 12/74 (JDC pc).

22. FRENCHMAN R. $13 \mathrm{KM}$ SE OF VAL MARIE. "Seen", Jy 4/37 (JDS-Soper 1970). 1 singing of (S5-T3-R12-W2M), My 24/77 (KF MJ PC).

23. FRENCHMAN R. AT U.S. BORDER. "Several", Jn 14-17/41 (JDS-Soper 1970). "Seen", My 17/70 (JDC pc). $10+$ singing of, My 23/77 (KF MJ pc).

24. BATTLE CK. (location imprecise; not mapped). "Noted sparingly", Jn 20/42 (JDS-Soper 1970).

25. CYPRESS HILLS (location imprecise; not mapped). 1 \& col (ROM), Jn 24/17 (HHM-DR pc). "Common", Jy-Ag/24 (MY-Williams 1946). Pr, nest with 8 fresh eggs col, Jn 1/25 (HHM-Bradshaw 1926). WOOD MTN.-BIG MUDDY AREA

26. KILLDEER BADLANDS INCL. ROCK AND MORGAN CK. 2 seen, 1 col, Jn 14/1895 (WSp-Macoun and Macoun 1909). "Not uncommon", Lonesome Butte, Sp 9-17/27 (JDS-Soper 1970). "A moderate no.", Rock Ck., Jn 5-8/40 (JDS-Soper 1970). 1 col, Jy 25/64 (CEKR pc). "Common", My 16/65 (RC GW WHB CE-KR pc). 12 seen, mostly singing o. My $24 / 75$ (WR KF MJ po). $5+$, Jn 15/76 (WH SL pc).

27. TWELVE-MILE L. Pr, Jn 5-7/40 (JDSSoper 1970).

28. FIFE L. "A moderate no.", 1 ò col, Jn 5-
8/40 (JDS-Soper 1970).

29. ROCKGLEN. 4 seen, Jy $16 / 77$ (BK pc). 1, Jn 16/76 (WH SL pc).

30. GOOSE CK. "Rather common; undoubtedly breeding", summer/75 (GA pc). 31. BIG MUDDY VALLEY \& L. "Not uncommon", Sp 18-27/27 (JDS-Soper 1970). "Fairly common", 1 t, 1 o col, Jn 5-7/38 (JDS-Soper 1970). Nest with 2 eggs, Jn 20/59 (RC-PNRS). "Common", My 30/65 (RC BH WHB-KR pc). 3, Jn 18/69 (JAW SW pc). 3, My 28/76 (DH pc).

32. AVONLEA BADLANDS. "Nesting", 1934 (obs?) (Bradshaw 1935).

33. HARP TREE. 1 of col (SMNH), Sp 22/30 (FGB-KR pc).

SOURIS R. DRAINAGE

34. SOURIS R. BADLANDS $W$ OF HALBRITE. 2, Ag 6/46 (JDS-Soper 1970). 35. COAL SPOILS NEAR ESTEVAN. "Up to 10 to 20 per day", summer/74 (BG pc). 2, Jn $7 / 77$ (DH pc).

36. ROCHE PERCEE. Late Ag/26 (Bradshaw 1927).

S. SASKATCHEWAN R.-LOWER SWIFT CURRENT CK.

37. LEMSFORD FY. "Nearly-fledged yng noted with parents", Jy 5/58 (GF pc).

38. S. SASKATCHEWAN R. $16 \mathrm{KM} \mathrm{S} \& 14$ KM E OF ESTON. 1 singing of , Jn 8-12/70 (JDR pc).

39. S. SASKATCHEWAN R. S OF ESTON. $4+$ in family group, $\mathrm{Ag} 3 / 72$ (AS pc).

40. S. SASKATCHEWAN R. $18 \mathrm{KM} \mathrm{S}$ OF WHITE BEAR. "Regularly noted; frequently seen carrying food into cracks", 1960's and 70's (SJ pc).

41. SASKATCHEWAN LANDING. 2, Ag 20/76 (BLy pc). 2, Sp 19/78 (GA pc).

42. MOUTH OF SWIFT CURRENT CK. 2, Jn 11/67 (JAW SW pc). Nest with 5 eggs, Jn 20/71 (WH-PNRS). "Several heard", Jn 23/73 (WH pc). 5, Jy 16/77 (BG pc).

43. S. SASKATCHEWAN R. N OF MAIN CENTRE. $2 \mathrm{col}$ (SMNH), Ag 11-12/64 (RC-KR pc).

44. MATADOR INTERNATIONAL BIOLOGICAL PROGRAMME GRASSLAND. "Uncommon summer resident", ESA: My 6/72; LFD: Ag 24/73; nest with 3 fledged yng, Jy 13/67 (MG); 5-6 in family group (2 col), Jy 22/67 (DS MG)(GA BF MG BP DS AS-AS pc, Maher 1974). 1 singing of , Sunken Hill, Jn 18/72 (WH pc).

45. S. SASKATCHEWAN R. AT RIVERHURST FY. "Pr with food", 1st wk Jy/76 (BLu-GA pc). 
QU'APPELLE R. DRAINAGE

46. PUMPING STATION AT BUFFALO POUND LAKE. Pr, Sp 12/59 (JWa-Knight 1967).

47. ARM R. VALLEY AT FINDLATER. 1 singing of, Ag 28 \& Sp 19/59 (MB-Callin, in prep.).

48. QU'APPELLE R. VALLEY AT MOOSE JAW CK. 1, Jn 29/77 (SL pc).

49. BRORA. 1, My 19-22/50 (TB-Belcher 1961).

50. VALEPORT. 1 t, $1 \% \mathrm{col}$, in breeding condition (SMNH), My 30/50 (FL-KR pc). 51. QU'APPELLE VALLEY AT BOGGY CK. 1 singing of, Jn 24/71 (MB BC Fr. Bedard-MB pc).

52. BOGGY CK. 1 , Ag $21 \& 24 / 64$ (DG-MB $\mathrm{pc})$.

53. CONDIE. 1, Jn/71 (FL-MB pc). 1, Jy 22/73 (FL-MB pc).

54. REGINA. 1, Wascana L., My $16 \& 21 / 59$ (FHB EF RFo-Belcher 1961). 1, My 14/59 (obs?) (Lahrman 1959). 1, Jy 15/59 (FLBelcher 1961). 3, Ag 28/59 (JMS DHSSpeirs \& Speirs 1960). 1, Sp 13/59 (FHB pc). 1, Ap 28/62 (MB pc). 1, My 15/65 (obs?) (Brazier 1965).

55. $7^{\circ} \mathrm{KM}$ E OF REGINA. 1, Ap 26/32 (HHM-Belcher 1961'.

56. PILOT BUTTE. "The nest, assumed to be in a cutbank of a gravel pit, was not located, but the pair was seen several times during the summer [of 1936]" (Belcher 1961); 1 juv $q$ col, Ag 15/36 (NA FGB-KR pc). 1, My 13/78 (RD-MB pc). 57. RICHARDSON. 1, My $17 / 59$ (FHBBelcher 1961'.

58. QU-APPELLE VALLEY FROM PASQUA L. TO A POINT $22 \mathrm{KM} \mathrm{W.} \mathrm{"5} \mathrm{and}$ possibly 6 birds at scattered points", Ag 30/59 (EMC-Callin, in prep).

59. PASQUA L. 1, My 10, Ag 24 \& Sp 15/59; 1 , My 15/60 (EMC-Callin, in prep). 60. LEBRET. 1 singing o , My $11 / 52$ (EMC-Callin, in prep).

61. QU'APPELLE VALLEY N OF BROADVIEW. 1, Sp 13/60 ("Thacker"-Callin, in prep).

62. SCISSOR CK. NEAR ROUND LAKE. 1 singing $\delta^{+}$, Jy $5 / 59$ (EMC-Callin, in prep). 63. PERCIVAL. 1, Jn 2/38 (EMC-Callin, in prep). 1 "remained for several days" about 1942 (EMC-Callin, in prep).

64. QU'APPELLE VALLEY N OF WHITEWOOD. 1, My 30/70 (EMC-Callin, in prep).

65. IMPERIAL. 1 singing $\delta$ in gravel pit (date ?) (FGB FL pc).
66. N END OF LAST MOUNTAIN L. (JWain Knight 1967).

OTHER AREAS

67. FLORAL. 1, Sp/74 (WM-Shadick 1975).

68. MUDDY L. HILLS S OF UNITY. $5+$ ad (incl $3+$ singing $\delta$ ); nest with $2+$ large yng, Jn 27/73 (WR JRo po). 1 singing ot Jn 27/78 (WR po).

69. KAZAN L. 1, Jn 12/42 (TR-Randall 1962).

\section{EASTERN ALBERTA}

70. MILK R. VALLEY. "Common", Jy/1895 (JM-Macoun \& Macoun 1909). "Noted 6 times", lower Milk R. gorge, Ag 13-Sp 1/23 (WM-Williams 1946). "within hearing at all times", My 30/71 (WSm-Smith 1972). 71. MEDICINE HAT. "Common in song", Jn 16/26 (MW-Williams 1946).

72. ELKWATER L. "Common ... until Ag 14"/26 (MW-Williams 1946).

73. RED DEER R. Breeds (Salt \& Salt 1976).

\section{NORTHEASTERN MONTANA}

74. FORT PECK DAM. $10+$ singing $\delta$ in rip-rap of embankment, summer/76 (CC pc).

75. $8 \mathrm{KM}$ E OF SAVOY. 1 singing $\delta$, My 29/72 (PS pc).

76. BOWDOIN NATIONAL WILDLIFE REFUGE. "Uncommon transient" (JF-PS pc).

77. MISSOURI R. AT WOLF POINT. 4 singing $\sigma^{*}, \mathrm{My} / 77 ; 1, \mathrm{Jn}-J y-A g / 77$ (LT_PS pc).

78. MISSOURI R. AT FT. UNION. Breeding (?) (JA-PS pC).

\section{NORTHWESTERN NORTH DAKOTA}

79. MISSOURI R. NEAR MOUTH OF LITTLE MUDDY CK. Probable breeding (Stewart 1975).

80. MISSOURI R. Probable breeding (Stewart 1975).

81. MISSOURI R. Probable breeding (Stewart 1975).

82. DES LACS R. Definite breeding locality (Stewart 1975).

83. MOUSE R. Definite breeding locality (Stewart 1975).

OBSERVERS, CORRESPONDENTS AND INSTITUTIONS

NA: Albulet, N., GA: Anweiler, Gary G., JA: Audubon, John J., FGB: Bard, Fred G., WHB: Beck, W. Harvey, MB: Belcher, Margaret, TB: Beveridge, Thos. M., FHB: Brazier, Frank H., EMC: Callin, E. Manley, CC: Carlson, Charles M., RC: Carson, 
Ralph D., JDC: Chandler, J. David, BC: Cruickshank, Betty, RD: Donison, Robyn, LD: Dreger, L., CE: Elliott, C., BF: Felske, Brian E., KF: Finley, Kerry J., RVF: Folker, Robert V., JF: Foster, John, EF: Fox, Elmer, GF: Fox, Glen A., RFo: Fox, Reginald, DG: Gilroy, Doug, WEG: Godfrey, W. Earl, BG: Godwin, Bob C., MG: Gollop, Michael A., WH: Harris, Wayne C., BH: Haysom, B., DH: Hjertaas, Dale G., CH: Holmes, Charles F., RH: Hooper, Ronald, MJ: Jasieniuk, Marie, SJ: Jordheim, Sig O., BK: Kreba, Bob, BLu: Luterbach, Bob, BLy: Lyon, Bruce, FL: Lahrman, Fred, HL: Laing, Hamilton M., SL: Lamont, Sheila M., JM: Macoun, John, WM: Maher, William J., SM: Mann, Steve A., HHM: Mitchell, H. Hedley, NMC: NATIONAL MUSEUM OF CANADA (Ottawa), WP-W: Plowden-Wardlaw, W.J., LP: Potter, Laurence B., PNRS: PRAIRIE NEST RECORD SCHEME, BP: Pylypec, Bohdan, TR: Randall, Thomas E., WR: Renaud, Wayne E., DR: Richardson, Dorothy M. (ROM), JDR: Rising, James D., R: Roney, Keith (SMNH), JRo: Rowe, John, ROM: ROYAL ONTARIO MUSEUM (Toronto), DSa: Sadler, Doug, SMNH: SASKATCHEWAN MUSEUM OF NATURAL HISTORY (Regina), SS: Schaafsma, Schewart, PS: Skaar, Palmer AS: Smith, Alan R., WSm: Smith, Wayne, JDS: Soper, J. Dewey, DSp: Speirs, Doris H., JMS: Speirs, J. Murray, WSp: Spreadborough, William, PT: averner, P. A., LT: Thompson, Larry, CET: Tull, C. Eric, JWa: Walker, John, GW: Watson, G., JAW: Wedgwood, Jim A., SW: Wedgwood, Shirley, JWi: Wilkinson, Jack, MW: Williams, M. Y., AW: Wisely, Al N.

\section{IST OF ABBREVIATIONS}

$d=$ adult, $A g=$ August,$A p=$ April, $C k$. $=$ reek, $\mathrm{col}=$ collected, $\mathrm{ESA}=$ earliest sprig arrival, $\mathrm{Fy} .=$ ferry, incl $=$ including, $\mathrm{Jn}$ June, Jy = July, juv = juvenile, $\mathrm{km}=$ ilometer, $\mathrm{L}$. = lake, LFD = latest fall leparture, $M=$ meridian, $M y=$ May, obs observer, $\mathrm{pC}=$ personal comnunication, po = personal observation, rep = preparation, $\mathrm{R}$. = river, Res. = eservoir, $\mathrm{Rg}=$ range, $\mathrm{S}=$ section, $\mathrm{Sp}=$ eptember, $\mathrm{T}=$ township, $\mathrm{yng}=$ young, $=$ male, $\Psi=$ female.

\section{Summary}

ROCK WREN (Salpinctes obsoletus). Locally common summer esident, 21 April to 27 September (usually early May to midSeptember). Breeds regularly along the Frenchman River and tributaries, Battle Creek and tributaries, upper Swift Current Creek near Dollard, Old Man On His Back Plateau, Boundary Plateau, Big Muddy Lake-Wood Mountain district (north locally to Avonlea), Estevan spoil piles, lower Swift Current Creek, South Saskatchewan River from the Alberta border to Riverhurst, Muddy Lake near Unity; probably breeds irregularly northeast to the north end of Last Mountain Lake, Pilot Butte near Regina, and in the Qu'Appelle Valley east to at least Pasqua Lake, perhaps to north of Whitewood. Occurs as a vagrant north to Floral and Kazan Lake. Nesting habitats include outcroppings of sedimentary bedrock, eroded river breaks, spoil piles; less regularly gravel pits, road cuts, riprap on dams and causeways. Forages in a variety of habitats including woodpiles, culverts, stone fences, and rock and cement piles.

\section{Acknowledgements}

This paper embraces the records of a large number of competent fieldnaturalists. I gratefully acknowledge all those persons listed in Table 1 whose observations form the basis of this review.

I especially wish to thank Margaret Belcher of Regina, E. Manley Callin of Ft. Qu'Appelle, Michael A. Gollop of Eastend, Palmer Skaar of Montana and Alan R. Smith of Edmonton (re: Matador I.B.P. Grassland) for providing detailed accounts of Rock Wrens in their respective areas. Keith Roney assembled information on specimens and unpublished records in the files of the Saskatchewan Museum of Natural History, Regina; and Dorothy Richardson made available a list of specimens in the Royal Ontario Museum, Toronto and the National Museum of Canada, Ottawa. Bob C. Godwin provided a detailed description of habitats oc- 
cupied by the Rock Wren in the Estevan area.

Kerry J. Finley, J. Bernie Gollop, Michael S. W. Bradstreet, C. Stuart Houston and W. John Richardson critically read early drafts of the manuscript. The technical support provided by LGL Ltd. in preparing this report is greatly appreciated.

'BELCHER, M. 1961. Birds of Regina. Spec. Publ. No. 3. Sask. Nat. Hist. Soc., Regina. 76 pp.

${ }^{2}$ BENT, A. C. 1948. Life Histories of North American nuthatches, wrens, thrashers, and their allies. Smithsonian Inst., U.S. Nat. Mus. Bull. 195. $475 p p+90$ plates.

BBRADSHAW, F. 1926. Report of Director, Provincial Museum of Natural Resources for year ending April 30, 1926. In: Ann. Rep. Dep. Railways, Labour and Industries. Govt. Prov. Saskatchewan, Regina.

${ }^{4}$ BRADSHAW, F. 1927. Report of Director, Provincial Museum of Natural Resources for year ending April 30, 1927. In: Ann. Rep. Dep. Railways, Labour and Industries. Govt. Prov. Saskatchewan, Regina.

${ }^{5}$ BRADSHAW, F. 1935. Report of Director, Provincial Museum of Natural Resources for year ending April 30, 1935. In: Ann. Rep. of Natural Resources. Govt. Prov. Saskatchewan, Regina.

${ }^{6}$ BRAZIER, F. H. 1965. Fifth annual May Day census, Regina. Blue Jay 23:132133.

${ }^{7}$ CALLIN, E. M. (in prep.). Birds of the Qu'Appelle River Valley. Spec. Publ. No. 10. Sask. Nat. Hist. Soc., Regina.

${ }^{8}$ FOLKER, R. V. 1961. Clark's Nutcracker, unusual visitor to Saskatchewan. Blue Jay 19:79.

${ }^{9}$ GODFREY, W. E. 1950. Birds of the Cypress Hills and Flotten Lake region, Saskatchewan. Nat. Mus. Can. Bull. No. 120 , Biol. Ser. 40. 96 pp.

${ }^{10}$ HOOPER, R. 1961. Some butterfly observations of 1961. Blue Jay 19:184.
${ }^{11 J E H L, ~ J . ~ R ., ~ J r ., ~ a n d ~ B . ~ A . ~ S M I T H . ~} 1970$ Birds of the Churchill Region Manitoba. Spec. Publ. No. 1 Manitoba Mus. Man and Nature, Win nipeg, Man. 87 pp.

${ }^{12} \mathrm{KNIGHT}$, L. M. 1967. Birds of the Moose Jaw area. Spec. Publ., Moose Jav Nat. Hist. Soc., Moose Jaw.

${ }^{13}$ LAHRMAN, F. W. 1959. A report or spring migration in Regina area 1959. Blue Jay 17:96-98.

${ }^{14}$ MACOUN, J. and J. M. MACOUN. 1909 Catalogue of Canadian birds. Geol Surv. Br., Dept. Mines, Ottawa.

${ }^{15}$ MAHER, W. J. 1974. Birds: II. Avifauna o the Matador area. Tech. Rep. No. 58 Canadian Comm. Internat. Biol Prog., Matador Project. Univ Saskatchewan, Saskatoon. 36 pp.

${ }^{16} \mathrm{MITCHELL}, H$. H. 1924 Birds o Saskatchewan. Can. Field-Nat 38:101-120.

17POTTER, L. B. 1932. Unusual nesting sites. Can. Field-Nat. 46:49.

${ }^{18}$ RANDALL, T. E. 1962. Birds of the Kazar Lake region, Saskatchewan. Blue Jay 20:60-72.

${ }^{19}$ ROY, J. F. 1964. An introduction to the birds of the Elbow. Sask. Nat. Hist Soc., Regina (Mimeo.). 33 pp.

${ }^{20}$ SALT, W. R. and J. R. SALT. 1976. The birds of Alberta. Hurtig Publishers, Edmonton, Alberta. 498 pp.

${ }^{21}$ SHADICK, S. 1975. Highlights of Saskatoon bird observations 1970 1974. Blue Jay 33:165-168.

${ }^{22}$ SMITH, W. W. 1972. Milk River Valley, Alberta-brief explorations. Blue Jay 30:49-51.

${ }^{23}$ SOPER, J. D. 1970. Unpublished field notes on the birds observed and collected in the province of Saskatchewan, Canada, in 1914, 1921, 1927 and from July, 1937 to September 1947. Zool. Dep., Univ. Alberta, Edmonton.,

${ }^{24}$ SPEIRS, J. M. and D. H. SPEIRS. 1960. Saskatchewan birds in August, 1959. Blue Jay 18:28-31.

${ }^{25}$ STEWART, R. E. 1975. Breeding birds of North Dakota. Tri-College Centre for Environ. Studies. Fargo, North Dakota. 295 pp.

${ }^{26}$ WILLIAMS, M. Y. 1946. Notes on the vertebrates of the southern plains of Canada, 1923-1926. Can. Field-Nat. 60:47-60. 